\title{
Root colonization with arbuscular mycorrhizal fungi and glomalin-related soil protein (GRSP) concentration in hypoxic soils from natural $\mathrm{CO}_{2}$ springs
}

\author{
Irena Maček, Damijana Kastelec and Dominik Vodnik \\ University of Ljubljana, Biotechnical Faculty, Department of Agronomy, Jamnikarjeva 101, SI-1001 Ljubljana, Slovenia \\ e-mail: irena.macek@bf.uni-lj.si
}

\begin{abstract}
Changed ratios of soil gases that lead to hypoxia are most often present in waterlogged soils, but can also appear in soils not saturated with water. In natural $\mathrm{CO}_{2}$ springs (mofettes), gases in soil air differ from those in typical soils. In this study, plant roots from the mofette area Stavešinci (Slovenia) were sampled in a spatial scale and investigated for AM fungal colonization. AM fungi were found in roots from areas with high geological $\mathrm{CO}_{2}$ concentration, however mycorrhizal intensity was relatively low and no correlation between $\mathrm{AM}$ fungal colonization and soil pattern of $\mathrm{CO}_{2} / \mathrm{O}_{2}$ concentrations (up to $37 \% \mathrm{CO}_{2}$ ) was found. The relatively high abundance of arbuscules in root cortex indicated existence of functional symbiosis at much higher $\mathrm{CO}_{2}$ concentrations than normally found in soils. In addition, concentration of two different glomalin-related soil protein fractions - EE-GRSP and TG-GRSP - was measured. No significant correlation between any of the fractions and soil gases was found, however the concentration of both fractions was significantly higher in the upper $0-5 \mathrm{~cm}$, compared to the $5-10 \mathrm{~cm}$ layer of the soil.
\end{abstract}

Key words: arbuscular mycorrhizal fungi, Glomeromycota, root colonization, GRSP, glomalin, natural $\mathrm{CO}_{2}$ springs, mofette, hypoxia, abiotic factors, extreme habitat, spatial distribution, soil fungi

\section{Introduction}

Arbuscular mycorrhizal (AM) fungi are obligatory biotrophic plant root endosymbionts, an ubiquitous functional group in soils, and are estimated to colonize around two thirds of plant species (Fitter and Moyersoen 1996). AM fungal symbiosis contributes significantly to global nutrient cycling and influences primary productivity in terrestrial ecosystems (Fitter 2005). AM fungi produce an extensive extra-radical mycelial network in soil and another AM fungal product, glomalin-related soil protein (GRSP), is transferred to soil via release from hyphae (Rillig et al. 2004, Driver et al. 2005). Glomalin has been reported to attribute a significant part, as much as 5\%, of soil C (Rillig et al. 2001, Rillig et al. 2003), and to affect soil structure by increasing the stability of soil aggregates (Rillig and Mummey 2006).

Evidence is accumulating that AM fungi are subject to strong selection pressures from the abiotic soil environment, such as pH and temperature (Dumbrell et al. 2010, Dumbrell et al. 2011), and also soil hypoxia (Maček et al. 2011). Hypoxia is a stress factor that can determine the composition of native AM fungal communities and affect the functioning of symbiosis (Maček et al. 2011). Normally, soil $\mathrm{CO}_{2}$ concentrations are about 50 -times higher (up to $2 \% \mathrm{CO}_{2}$ ) than ambient atmospheric $\mathrm{CO}_{2}$ concentration, and often fluctuate due to soil compaction, waterlogging, and/or vegetation (Bouma and Bryla 2000, Pfanz et al. 2004). Natural $\mathrm{CO}_{2}$ springs (mofettes) are extreme ecosystems where soil $\mathrm{CO}_{2}$ concentration can reach values above $80 \% \mathrm{CO}_{2}$ in the upper $10-20 \mathrm{~cm}$ of soil in the most extreme sites, representing a consistent environmental impact of the displacement of the soil atmosphere by $\mathrm{CO}_{2}$, leading to localized hypoxia 


\section{AGRICULTURAL AND FOOD SCIENCE}

I. Macek et al. (2012) 21: 62-71

(Vodnik et al. 2006). Most of the research at natural $\mathrm{CO}_{2}$ springs in the past has been focused on aboveground responses of vegetation (Raschi et al. 1997, Badiani et al. 1999, Vodnik et al. 2002a, 2002b, Pfanz et al. 2004, Pfanz et al. 2007). Much less work has been done on the below ground responses of plants (Maček et al. 2005) or AM fungi (Rillig et al. 2000, Maček et al. 2011). Rillig et al. (2000) reported a linear correlation between atmospheric $\mathrm{CO}_{2}$ concentration and AM fungal root colonization, soil hyphal length, and glomalin concentration in a mofette, but discussed results mainly with respect to global atmospheric $\mathrm{CO}_{2}$ increase and did not consider the effects of gas composition in the mofette soil. The latter has been proved as a crucial factor of plant (Vodnik et al. 2002a, 2002b, Pfanz et al. 2004, 2007) and microbial (Videmšek et al. 2009, Maček et al. 2011) performance. Despite limitations with experimentation on mofettes it has been recognized that they can be very efficiently used to study the effects of unique soil gaseous conditions on soil and plant processes. In this respect they can also serve as a model system to investigate the response of AM fungi to soil hypoxia.

The objectives of the present study were: (i) to quantify AM fungal colonization in plant roots in response to exposure to a gradient of soil $\mathrm{CO}_{2} / \mathrm{O}_{2}$ concentrations in the extreme environment of the Stavešinci mofette in a spatial pattern; and (ii) to analyze different fractions of soil GRSP when exposed to extreme soil $\mathrm{CO}_{2}$ concentrations within this ecosystem.

\section{Materials and Methods}

\section{Soil gas measurements and sampling}

The study was conducted in 2003 in Stavešinci mofette area, NE Slovenia (for detailed description of the site see Vodnik et al. 2006, 2009b). The site is a flat post-agricultural area where geological $\mathrm{CO}_{2}$ of ambient temperature, without traces of sulphur compounds, $\mathrm{CH}_{4}$ or $\mathrm{CO}$, is released into atmosphere via several vents (Vodnik et al. 2002a). The existing vegetation at the study site consists of $\mathrm{C}_{3}$ and $\mathrm{C}_{4}$ grasses, dominated by Poa pratensis L., Dactylis glomerata L., Holcus lanatus L., Phleum pratense L., Setaria pumila (Pior.) Roem \& Schult, Echinochloa crus-galli (L.) PB, common grassland plants and some ruderals (Vodnik et al. 2002a, Pfanz et al. 2007). Because atmospheric $\mathrm{CO}_{2}$ concentrations vary, depending on weather and wind conditions, from ambient to at least $1 \%$ at $0.5 \mathrm{~m}$ above-ground level (Vodnik et al. 2006), soil $\mathrm{CO}_{2}$ concentration was found to be a better estimate of plant exposure to geological $\mathrm{CO}_{2}$. Therefore, soil $\mathrm{CO}_{2}$ and $\mathrm{O}_{2}$ concentrations were measured by a portable gas analyzer GA2000 (Ansyco, Germany, method described in Vodnik et al. 2006) in two mofette locations, Plot 1 and Plot 2 (Fig. 1). For Plot 1 soil and root samples were taken in September 2003 in a regular sampling grid of 58 sampling points ( $1 \mathrm{~m}$ resolution) using a soil probe $(\varnothing$ $=10 \mathrm{~cm}, 10 \mathrm{~cm}$ depth) in an area around a $\mathrm{CO}_{2}$ vent (mofette) with soil $\mathrm{CO}_{2}$ concentrations ranging from high $\mathrm{CO}_{2}\left(\max 37 \% \mathrm{CO}_{2}\right)$ to ambient (control). Details on soil $\mathrm{CO}_{2}$ and $\mathrm{O}_{2}$ concentrations are shown in Fig. 2. Gas measurements within the Plot 1 were performed after soil sampling in December 2003 (Fig. 2). Since the soil $\mathrm{CO}_{2}$ concentrations within Plot 1 did not reach the range of maximum concentrations that have already been measured in other studies within the Stavešinci mofette area (Vodnik et al. 2006), 29 additional soil samples were taken in a second, more extreme site (Plot 2). Samples were taken following soil air gas measurements for each sampling point in December 2003 by using a soil probe $(\varnothing=2 \mathrm{~cm}$, in two soil depths $0-5 \mathrm{~cm}$ and $5-10 \mathrm{~cm}$ ) in a range of soil $\mathrm{CO}_{2}$ concentrations from the control $(<3 \%)$ to the $\max (76 \%)$ (Fig.3). All samples were stored at $4{ }^{\circ} \mathrm{C}$ until further analyses. For both areas, the physical and chemical properties of the soil have been described before (Maček et al. 2009, 2011). 


\section{AGRICULTURAL AND FOOD SCIENCE}

I. Macek et al. (2012) 21: 62-71

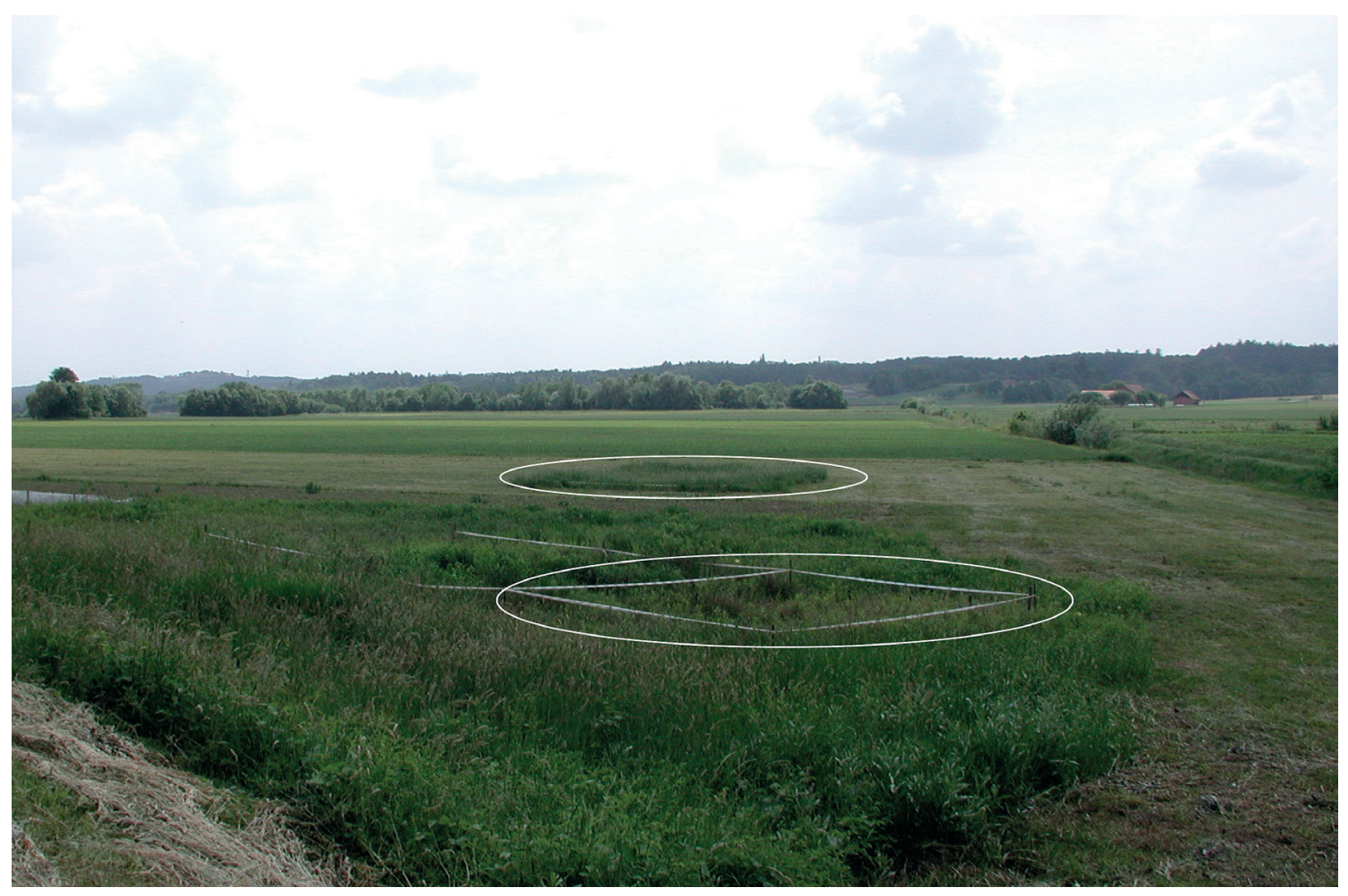

Fig. 1. Natural $\mathrm{CO}_{2}$ springs in Stavešinci mofette area. Sampling locations Plot 1 (back) and Plot 2 (front) are indicated by the oval lines.

\section{AM fungal colonization}

Roots were extracted from soil separately for each soil core within two weeks after sampling and stored in $70 \% \mathrm{EtOH}$. Roots were cleared with hot $10 \% \mathrm{KOH}$ and acidified with $1 \mathrm{~N} \mathrm{HCl}$. The fungal tissue inside roots was stained with $0.05 \%$ trypan blue in lactoglycerol. The AM fungal root colonization was assessed following Trouvelot et al. (1986) using an Olympus Provis AX70 microscope ( $n=30$ one cm root fragments from each soil core).

\section{GRSP concentration}

In each sample the soil was mixed and four replicates of $1 \mathrm{~g}$ subsamples were processed to extract easily extractable Bradford reactive soil protein (EE-GRSP, for terminology see Rillig 2004) and Bradford reactive soil protein after extensive extraction (TG-GRSP). The extraction method was described by Wright and Upadhyaya (1996) and Rillig et al. (2001). In short, replicate samples of sieved 1-2 mm soils were extracted with $2 \mathrm{ml}$ of extractant. EE-GRSP was extracted with $20 \mathrm{mM}$ citrate, pH 7.0 at $121{ }^{\circ} \mathrm{C}$ for $30 \mathrm{~min}$. TG-GRSP was extracted with $50 \mathrm{mM}$ citrate, $\mathrm{pH} 8.0$ at $121^{\circ} \mathrm{C}$. Extraction of a TG-GRSP sample continued until the supernatant showed none of the red-brown color typical of glomalin (Wright and Upadhyaya 1996). Glomalin concentration was determined by the Bradford protein assay using 96-well plates as previously described for hyphae and soil extracts. Extracts were centrifuged at 10,000 RPM for 5 min to remove insoluble material. 


\section{AGRICULTURAL AND FOOD SCIENCE}

I. Macek et al. (2012) 21: 62-71

Bovine serum albumin standards were used in a range of 1.25 to $5.0 \mathrm{mg}$ well ${ }^{-1}$. The volume of extract tested was $50 \mathrm{ml}$, and blanks containing $50 \mathrm{ml}$ of $20 \mathrm{mM}$ citrate were used to correct for citrate in test samples.

\section{Statistical analyses}

Spatial distribution of soil $\mathrm{CO}_{2}$ and $\mathrm{O}_{2}$ concentration was presented (size of a dot in a figure corresponds to classes of measured variables). The Pearson or Spearman correlation coefficients were used as a measure of relationship between different variables. The averages of EE-GRSP and TG-GRSP concentrations in two soil layers $(0-5 \mathrm{~cm}, 5-10 \mathrm{~cm})$ were statistically compared using a paired t-test.

\section{Results}

Within the Plot 1 the maximum measured soil $\mathrm{CO}_{2}$ concentration in the high $\mathrm{CO}_{2}$ area was $36.9 \%$ (corresponding $\mathrm{O}_{2}$ concentration $10.7 \%$ ) and minimum $\mathrm{CO}_{2}$ concentration in the control area $0.2 \%$ (corresponding $\mathrm{O}_{2}$ concentration $17.0 \%$ ) (Fig. 2). A wider range of $\mathrm{CO}_{2} / \mathrm{O}_{2}$ concentrations were measured within the second location (Plot 2), ranging from control $\left(<1 \% \mathrm{CO}_{2}\right)$ up to maximum $76.1 \% \mathrm{CO}_{2}$ in soil air (Fig. 3). At both studied plots high correlation between soil $\mathrm{CO}_{2}$ and $\mathrm{O}_{2}$ concentration was found, as indicated by the Spearman's correlation coefficient -0.96 (Figs. 2 and 3).

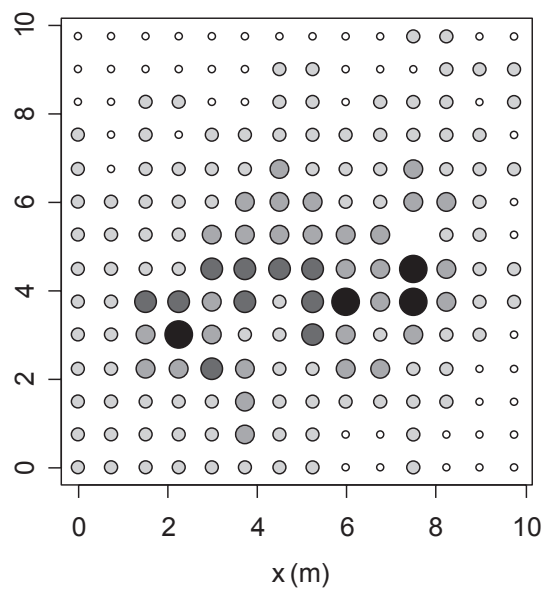

Soil $\mathrm{CO}_{2}$ concentration

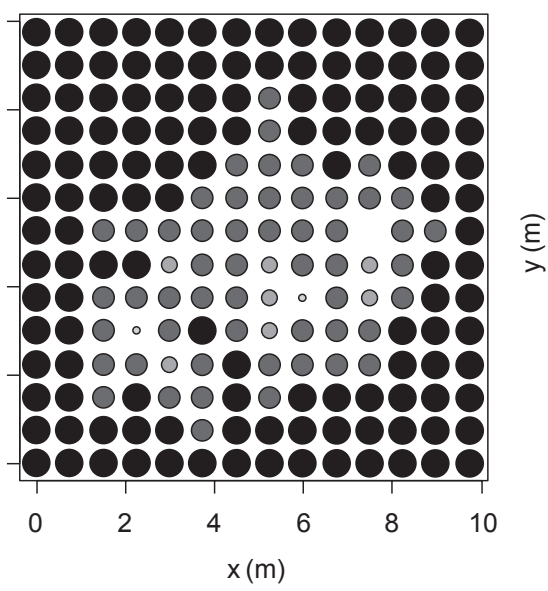

Soil $\mathrm{O}_{2}$ concentration

Fig. 2. The spatial pattern of soil $\mathrm{CO}_{2}$ (left) and $\mathrm{O}_{2}$ (right) concentrations in a $10 \mathrm{x} 10 \mathrm{~m}$ area (x and y axes) in Stavešinci (Plot 1). The centre of a dot indicates the soil-gas sampling point. The sizes and the color intensity of the dots correspond to the class of soil $\mathrm{CO}_{2} / \mathrm{O}_{2}$ concentrations. 


\section{AGRICULTURAL AND FOOD SCIENCE}

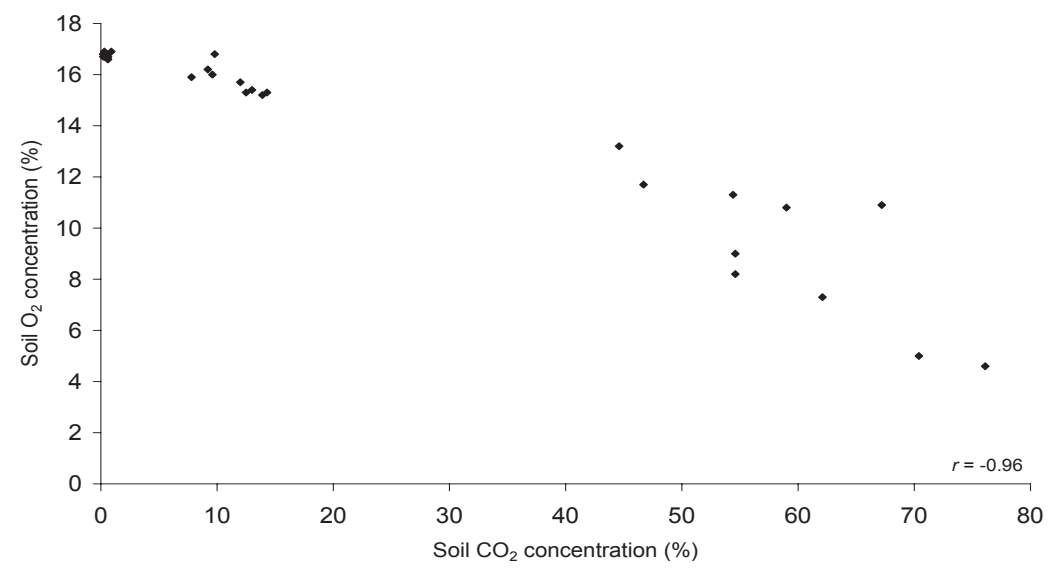

Fig. 3. The correlation between soil $\mathrm{CO}_{2}$ and $\mathrm{O}_{2}$ concentrations within Stavešinci mofette Plot 2 .

We found only $7 \%$ of root samples highly colonized with AM fungi ( $M$ - fungal intensity in roots $>45 \%$ ) within Plot 1 (Fig. 4). M was significantly correlated with the arbuscule density (a) in the colonized root cortex (Spearman's correlation coefficient 0.53 ). The arbuscule density was relatively high and reached over $60 \%$ in $67 \%$ of the root samples (Fig. 4), which reflects physiological compatibility of the symbionts. No significant correlation between AM fungal colonization parameters and soil gases $\left(\mathrm{CO}_{2}\right.$ or $\left.\mathrm{O}_{2}\right)$ was found.

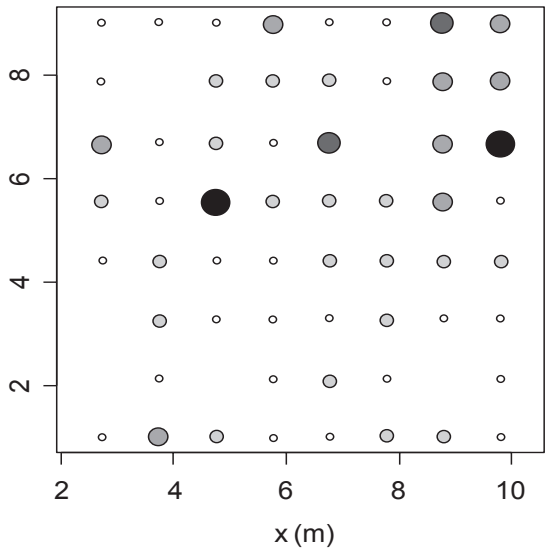

Mycorrhizal intensity - M (\%)

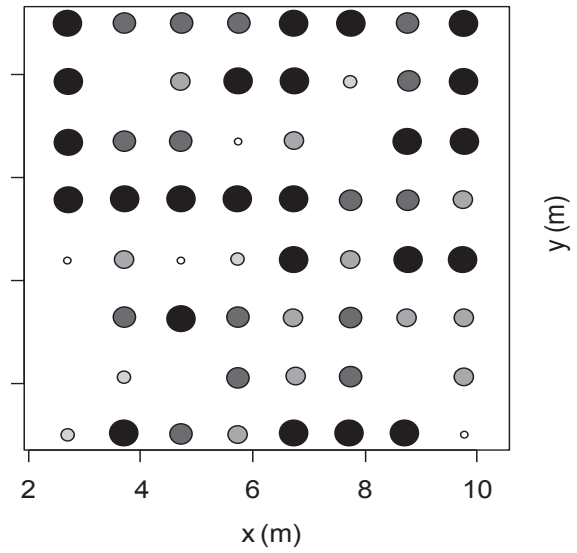

Arbuscule density - a (\%)

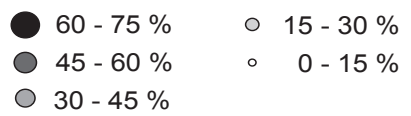

Fig. 4. Spatial presentation of AM fungal intensity (M) in roots (left), and the density of arbuscules (a) in the colonized root cortex (right) in an $8 \times 8 \mathrm{~m}$ area (x and y axes) in Stavešinci mofette (subplot within Plot 1). The centre of a dot indicates soil core $(\varnothing=10 \mathrm{~cm}, 10 \mathrm{~cm}$ depth) sampling location. The sizes of the dots and the color intensity correspond to the class of the measured variable. 


\section{AGRICULTURAL AND FOOD SCIENCE}

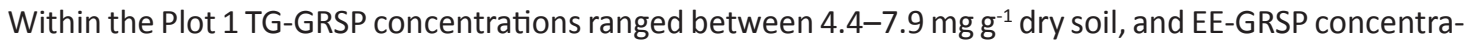
tions between 1.1-2.1 mg g ${ }^{-1}$ dry soil (Fig. 5). Spearman's correlation coefficient 0.59 indicates significant correlation between both GRSP fractions, however no significant correlation between any of the GRSP fractions and soil gases $\left(\mathrm{CO}_{2}\right.$ or $\left.\mathrm{O}_{2}\right)$ was found.

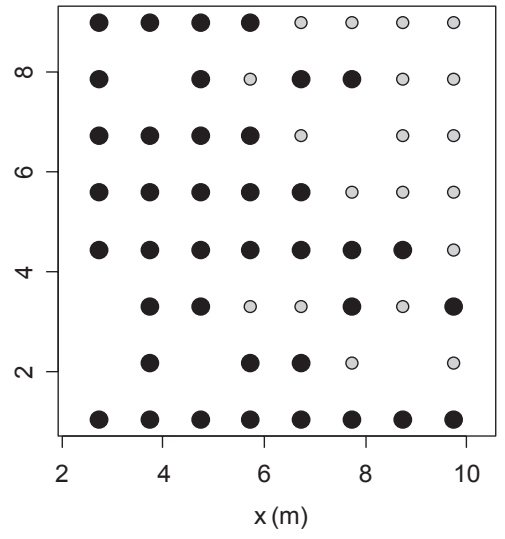

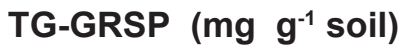

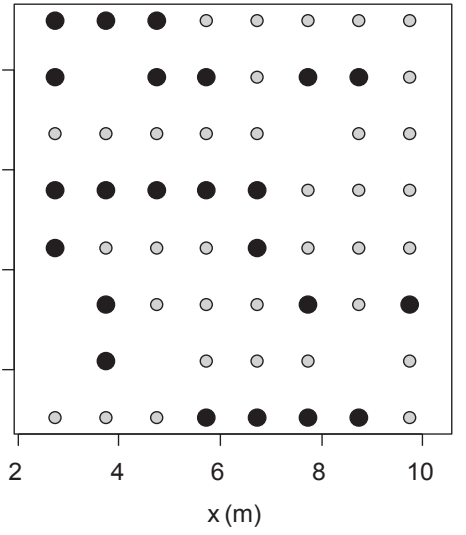

EG-GRSP (mg g-1 soil)
Fig. 5. Spatial distribution of the soil's total TG-GRSP (left), and the easily extractable EEGRSP (right) concentra$\widehat{\varepsilon}$ tions in an $8 \times 8 \mathrm{~m}$ area $(\mathrm{x}$ and y axes) in Stavešinci mofette (subplot within Plot 1). The centre of a dot indicates soil core $(\varnothing$ $=10 \mathrm{~cm}, 10 \mathrm{~cm}$ depth) sampling location. The sizes of the dots and the color intensity correspond to the class of the GRSP concentration.

The highest concentrations of TG-GRSP (10.6 $\mathrm{mg} \mathrm{g}^{-1} \mathrm{dry}$ soil) and EE-GRSP ( $4.6 \mathrm{mg} \mathrm{g}^{-1}$ dry soil) within the Stavešinci mofette area measured within this study coincided with the location (Plot 2) where the highest concentrations of geological gas were measured $\left(76.1 \% \mathrm{CO}_{2}\right.$ (Fig. 3)). The soil concentrations of both GRSP fractions were correlated with Pearson's correlation coefficients values $0.46(0-5 \mathrm{~cm}$ soil layer) and 0.72 (5-10 cm soil layer), see Fig. 6. However, similar to Plot 1 (Figs. 2 and 5), no correlation between soil gases and any of the GRSP fractions was found.

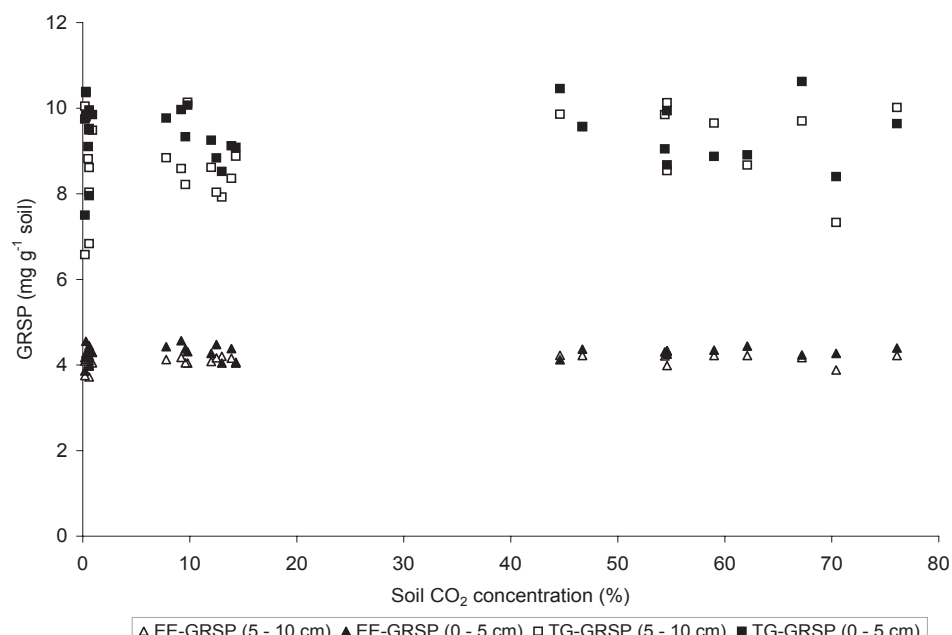

Fig. 6. The concentration of TG-GRSP and EEGRSP in two soil depths $(0-5$ and $5-10 \mathrm{~cm})$ and different soil $\mathrm{CO}_{2} / \mathrm{O}_{2}$ concentrations within Plot 2.

$\triangle$ EE-GRSP $(5-10 \mathrm{~cm}) \Delta$ EE-GRSP $(0-5 \mathrm{~cm})$ 口TG-GRSP $(5-10 \mathrm{~cm})$ - TG-GRSP $(0-5 \mathrm{~cm})$ 


\section{AGRICULTURAL AND FOOD SCIENCE}

I. Macek et al. (2012) 21: 62-71

Concentrations of EE-GRSP were significantly $(p=0.0000)$ higher in the upper, $0-5 \mathrm{~cm}$, soil layer $(4.3 \pm 0.03$ $\mathrm{mg} \mathrm{g}^{-1}$ dry soil) compared to $\left(4.1 \pm 0.03 \mathrm{mg} \mathrm{g}^{-1} \mathrm{dry}\right.$ soil) in the lower $5-10 \mathrm{~cm}$ soil layer. In addition, significant differences ( $p=0.0012$ ) in TG-GRSP concentrations were found for both soil depths, with the average of $9.4 \pm 0.14 \mathrm{mg} \mathrm{g}^{-1}$ dry soil in the $0-5 \mathrm{~cm}$ layer and $8.9 \pm 0.19 \mathrm{mg} \mathrm{g}^{-1}$ dry soil in the $5-10 \mathrm{~cm}$ layer.

\section{Discussion}

This study highlights the response of AM fungal root colonization and soil concentrations of AM fungal product glomalin-related soil protein (GRSP) to a gradient of concentrations of soil gases $\left(\mathrm{CO}_{2}\right.$ and $\left.\mathrm{O}_{2}\right)$ in mofette environment (natural $\mathrm{CO}_{2}$ springs).

Soils can be often depleted in $\mathrm{O}_{2}$ due to waterlogging and flooding. A similar situation occurs at natural $\mathrm{CO}_{2}$ springs, where displacement of the soil atmosphere by $\mathrm{CO}_{2}$ leads to localized hypoxia or even anoxia (Vodnik et al. 2006). In arbuscular mycorrhizas a part of the fungus (intraradical mycelium) lives in the primary root cortex, where the exchange between both partners in the symbiosis takes place, a second part extends into soil (extraradical mycelium). Root environment can be enriched in $\mathrm{CO}_{2}$ and depleted (or enriched) in $\mathrm{O}_{2}$, mostly due to root metabolism (Le Tacon et al. 1983) and other plant derived processes (aerenhymal tissues) (Vodnik et al. 2009a) and can differ from the gaseous conditions found in the surrounding soil. In the most extreme mofette sites, AM fungi are most probably not being supported by mycelium in surrounding soil and the root environment may play an important role in providing sufficient amount of $\mathrm{O}_{2}$ for aerobic respiration of symbiotic fungi, which would be an obvious explanation as to how these aerobic organisms might survive in hypoxic or anoxic soils. We showed, that despite the prolonged stress and the carbon cost of colonization, no correlation between geological gas emission $\left(\mathrm{CO}_{2}\right.$ concentrations up to $37 \%$, Fig. 2) and AM fungal root colonization was found, however mycorrhizal intensity in roots was relatively low (Fig. 4). Le Tacon et al. (1983) report on the reduced spore germination rate in the AM fungal species Glomus mossae in hypoxic conditions, in addition, decreasing $\mathrm{O}_{2}$ concentration from $21 \%$ to $3 \%$ reduced hyphal growth. The same authors suggested that reduced $\mathrm{O}_{2}$ partial pressure in the root intracellular environment, resulting from the root metabolism, could be an important factor for endophyte growth and development. The optimum concentration of $\mathrm{O}_{2}$ for the formation of arbuscules is suggested to be $8-12 \%$. Saif (1981) reports on the lower rate of Glomus macrocarpus root colonization in Eupatorium odoratum L. only below $2 \% \mathrm{O}_{2}$ in the atmosphere. For our study, roots were sampled at location where concentration of $\mathrm{O}_{2}$ in soil air was still relatively high $(10.7 \%$, Fig. 2$)$ in the most exposed site to geological $\mathrm{CO}_{2}$, thus most probably no direct effect of soil hypoxia was present.

Some of our previous work (Vodnik et al. 2002a,b; Pfanz et al. 2007) showed the negative effect of high geological $\mathrm{CO}_{2}$ concentration on photosynthesis and growth in mofette plants. Thus, as a significant sink for assimilated carbon, AM fungi could also be affected by a reduced carbon supply and not only by a direct influence of the soil gaseous regime. Relatively high abundance of arbuscules (Fig. 4) in plant roots from Stavešinci mofette indicates the physiological compatibility and exchange of nutrients between the symbionts also in this specific environment. Interestingly, one of our recent studies showed that distant assemblages of AM fungi are found in locations with high soil $\mathrm{CO}_{2}$ concentrations (high $\mathrm{CO}_{2}$ ) and control sites within Stavešinci mofette area (Maček et al. 2011). This was confirmed in both, sites with moderately (Plot 1) and extremely elevated soil $\mathrm{CO}_{2}$ (Plot 2), which were the same as those used for this study. The molecular data showed that, though $\mathrm{CO}_{2}$ concentration in Plot 1 was not as extreme as in Plot 2 (Figs. 2 and 3), the most abundant phylotype of AM fungi found in both high $\mathrm{CO}_{2}$ sites was the same. This same AM phylotype was exclusive to high $\mathrm{CO}_{2}$ sites and was completely absent in control sites, indicating a high level of AM fungal community turnover between high $\mathrm{CO}_{2}$ and control sites. Thus, though AM fungal root 


\section{AGRICULTURAL AND FOOD SCIENCE}

I. Macek et al. (2012) 21: 62-71

colonization, as measured in this study, indicates the overall presence of mycorrhizal fungi in plant roots regardless of the soil gas regime, only studies employing molecular tools, can give more information on AM fungal communities and their composition in a certain environment.

A second parameter, indicating long-term presence of AM fungi in mofette areas, is glomalin (GRSP glomalin-related soil protein, see Rillig (2004), a glycoprotein produced by AM fungi (Wright and Upadhyaya 1996). Standing stocks of glomalin in soil are determined by its production and decomposition and environmental factors could affect the two fluxes independently (Rillig 2004). Using Bradford reactive soil protein measurement (Wright and Upadhyaya 1996) we found relatively high amounts of GRSP (TGGRSP up to $7.9 \mathrm{mg} \mathrm{g}^{-1}$ dry soil) in Plot 1 . The TG-GRSP concentrations found in Stavešinci mofette are in the range of those found by Rillig et al. (2000) in mofette sites in New Zealand and Vodnik et al. (2008) in a FACE experiment. However, no data on soil $\mathrm{CO}_{2}$ or $\mathrm{O}_{2}$ concentrations are presented in the study from the New Zealand mofette site. Interestingly, the highest concentrations of GRSP (TG-GRSP $10.6 \mathrm{mg} \mathrm{g}^{-1}$ and EE-GRSP $4.6 \mathrm{mg} \mathrm{g}^{-1}$ dry soil) within the Stavešinci mofette area coincided with the location where the highest concentrations of geological gas were measured (soil $\mathrm{CO}_{2}$ concentration $76.1 \%$ within this study, see also Vodnik et al. 2006) and corresponding $\mathrm{O}_{2}$ concentration 4.6\%, indicating soil hypoxia. Though some plants are mycorrhizal also in the most extreme areas (for Plot 2 see Maček et al. 2011) and thus some glomalin must be produced, the plant (root) biomass in those areas is small. The factor affecting glomalin accumulation in the extremely high $\mathrm{CO}_{2}$ concentrations in soil is most probably a change in microbial decomposition. Indeed, measurements of microbial respiration and microbial biomass in soils from the Stavešinci natural $\mathrm{CO}_{2}$ spring clearly demonstrated higher microbial respiration and higher microbial biomass in control sites compared to high soil $\mathrm{CO}_{2}$ sites (Maček et al. 2009).

This work presents one of the few studies on AM fungi in mofette areas. We showed that despite the prolonged stress, root colonization with AM fungi also exists in sites with extreme soil $\mathrm{CO}_{2}$ concentrations that can lead to soil hypoxia. In addition, relatively high concentrations of AM fungal product GRSP can be found in the most extreme sites in Stavešinci mofette area. A possible explanation for that is slow decomposition of GRSP in hypoxic soil.

\section{Acknowledgements}

This work was supported by the Slovenian Research Agency (programme no. P4-0085 and projects no. Z4-9295 and J4-2235). We thank to Prof. Dr. Hardy Pfanz from University Duisburg-Essen for providing access to the field equipment and to Martina Gajšek for technical assistance. We are grateful to Action COST 870 for providing support for further development of the research on biology and application of AM fungi in Slovenia.

\section{References}

Badiani, A., Raschi, A., Paolacci, A.R. \& Miglietta, F. 1999. Plant responses to elevated $\mathrm{CO}_{2}$ : a prospective from natural $\mathrm{CO}_{2}$ springs. In: Agrawal, S.B. \& Agrawal, M. (eds.). Environmental Pollution and Plant Responses. CRC Press LLC, Boca Raton: p. 45-81.

Bouma, T.J. \& Bryla, D.R. 2000. On the assessment of root and soil respiration for soils of different textures: interactions with soil moisture contents and soil $\mathrm{CO}_{2}$ concentrations. Plant \& Soil 227: 215-221.

Driver, J.D., Holben, W.E., Rillig, M.C. 2005. Characterization of glomalin as a hyphal wall component of arbuscular mycorrhizal fungi. Soil Biology \& Biochemistry 37: 101-106. 


\title{
AGRICULTURAL AND FOOD SCIENCE
}

\author{
I. Macek et al. (2012) 21: 62-71
}

Dumbrell, A.J., Gu, F., Ashton, P.D., Aziz, N., Nelson, M., Dytham, C., Fitter, A.H. \& Helgason, T. 2011. Distinct seasonal assemblages of arbuscular mycorrhizal fungi revealed by massively parallel pyrosequencing. New Phytologist 190: 794-804.

Dumbrell, A.J., Nelson, M., Helgason T., Dytham, C. \& Fitter, A.H. 2010. Relative roles of niche and neutral processes in structuring a soil microbial community. ISME Journal 4: 337-345.

Fitter, A.H. 2005. Darkness visible: reflections on underground ecology. Journal of Ecology 93: 231-243.

Fitter, A.H. \& Moyersoen, B. 1996. Evolutionary trends in root microbe symbioses. Philosophical Transactions of the Royal Society B: Biological Sciences 351(1345): 1367-1375.

Le Tacon, F., Skinner, F.A. \& Mosse, B. 1983. Spore germination and hyphal growth of a vesicular-arbuscular mycorrhizal fungus, Glomus mosseae (Gerdemann and Trappe), under decreased oxygen and increased carbon dioxide concentrations. Canadian Journal of Microbiology 29: 1280-1285.

Maček, I., Dumbrell, A.J., Nelson, M., Fitter, A.H., Vodnik, D. \& Helgason, T. 2011. Local adaptation to soil hypoxia determines the structure of an arbuscular mycorrhizal fungal community in roots from natural $\mathrm{CO}_{2}$ springs. Applied and Environmental Microbiology 77: 4770-4777.

Maček, I., Pfanz, H., Francetič, V., Batič, F. \& Vodnik, D. 2005. Root respiration response to high $\mathrm{CO}_{2}$ concentrations in plants from natural $\mathrm{CO}_{2}$ springs. Environmental and Experimental Botany 54: 90-99.

Maček, I., Videmšek, U., Kastelec, D., Stopar, D. \& Vodnik, D. 2009. Geological $\mathrm{CO}_{2}$ affects microbial respiration rates in Stavešinci mofette soils. Acta Biologica Slovenica 42(2): 41-48.

Pfanz, H., Vodnik, D., Wittmann, C., Aschan, G., Batič, F., Turk, B. \& Maček, I. 2007. Photosynthetic performance (CO compensation point, carboxylation efficiency, and net photosynthesis) of timothy grass (Phleum pratense L.) is affected by elevated carbon dioxide in post-volcanic mofette areas. Environmental and Experimental Botany 61: 41-48.

Pfanz, H., Vodnik, D., Wittmann, C., Aschan, G. \& Raschi, A. 2004. Plants and geothermal CO, exhalations. Survival and adaptation to a high $\mathrm{CO}_{2}$ environment. In: Esser, K., Lüttge, U., Kadereit, J.W. \& Beyschlag, W. (eds.) Progress in Botany 65: 499-538.

Raschi, A., Miglietta, F., Tognetti, R. \& van Gardingen, P.R. 1997. Plant responses to elevated $\mathrm{CO}_{2}$. Evidence from natural $\mathrm{CO}_{2}$ springs. Cambridge University Press, Cambridge, UK: 272 p.

Rillig, M.C. 2004. Arbuscular mycorrhizae, glomalin, and soil aggregation. Canadian Journal of Soil Science 84: $355-363$.

Rillig, M.C., Hernandez, G.Y. \& Newton, C.D. 2000: Arbuscular mycorrhizae respond to elevated atmospheric $\mathrm{CO}_{2}$ after long-term exposure: evidence from a $\mathrm{CO}_{2}$ spring in New Zealand supports the resource balance model. Ecology Letters 3: 475-478.

Rillig, M.C. \& Mummey, D.L. 2006. Mycorrhizas and soil structure. New Phytologist 171: 41-53.

Rillig, M.C., Ramsey, P.W., Morris, S. \& Paul, E.A. 2003. Glomalin, an arbuscular-mycorrhizal fungal soil protein, responds to land-use change. Plant \& Soil 253: 293-299.

Rillig, M.C., Wright, S.F., Nichols, K.A., Schmidt, W.F. \& Torn, M.S. 2001. Large contribution of arbuscular mycorrhizal fungi to soil carbon pools in tropical forest soils. Plant \& Soil 233: 167-177.

Saif, S.R. 1981. The influence of soil aeration on the efficiency of vesicular-arbuscular mycorrhizae. 1 . Effect of soil oxygen on the growth and mineral uptake of Eupatorium odoratum L. inoculated with Glomus macrocarpus. New Phytologist 88: 649-659.

Trouvelot, A., Kough, J.L. \& Gianinazzi-Pearson, V. 1986. Mesure du taux de mycorhization VA d'un système radiculaire. Recherche de méthodes d'estimation ayant une signification fonctionnelle. In: Gianinazzi-Pearson, V. \& Gianinazzi, S. (eds.). Physiological and genetical aspects of mycorrhizae. INRA Press, Paris, France: p. 217-221.

Videmšek, U., Hagn, A., Suhadolc, M., Radl, V., Knicker, H., Schloter, M. \& Vodnik, D. 2009. Abundance and diversity of $\mathrm{CO}_{2}$-fixing bacteria in grassland soils close to natural carbon dioxide springs. Microbial Ecology 58: 1-9.

Vodnik, D., Kastelec, D., Pfanz, H., Maček, I. \& Turk, B. 2006. Small-scale spatial variation in soil $\mathrm{CO}_{2}$ concentration in a natural carbon dioxide spring and some related plant responses. Geoderma 133: 309-319.

Vodnik, D., Maček, I., Péli, E., Videmšek, U. \& Tuba, Z. 2008. Elevated $\mathrm{CO}_{2}$ affects the content of glomalin related soil protein in xeric temperate loess and temperate semi-desert sand grasslands. Community Ecology 9: 161-166.

Vodnik, D., Pfanz, H., Maček, I., Kastelec, D., Lojen, S. \& Batič, F. 2002a. Photosynthetic performance of cockspur (Echinochloa crus-galli (L.) Beauv.) at sites of naturally elevated $\mathrm{CO}_{2}$. Photosynthetica 40: 575-579. 


\section{AGRICULTURAL AND FOOD SCIENCE}

I. Macek et al. (2012) 21: 62-71

Vodnik, D., Pfanz, H., Wittmann, C., Maček, I., Kastelec, D., Turk, B. \& Batič, F. 2002b. Photosynthetic acclimation in plants growing near a carbon dioxide spring. Phyton - Annales Rei Botanicae 42(3): 3: 239-244.

Vodnik, D., Strajnar, P., Jemc S. \& Maček, I. 2009a. Respiratory potential of maize (Zea mays L.) roots exposed to hypoxia. Environmental and Experimental Botany 65: 107-110.

Vodnik, D., Videmšek, U., Pintar, M., Maček, I. \& Pfanz, H. 2009b. The characteristics of soil $\mathrm{CO}_{2}$ fluxes at a site with natural $\mathrm{CO}_{2}$ enrichment. Geoderma 150: 32-37.

Wright, S.F. \& Upadhyaya, A. 1996. Extraction of an abundant and unusual protein from soil and comparison with hyphal protein of arbuscular mycorrhizal fungi. Soil Science: 161: 575-586. 